\title{
The effect of epidural cooling on lipid peroxidation after experimental spinal cord injury
}

\author{
S Tüzgen ${ }^{1}$, MY Kaynar ${ }^{1}$, A Güner ${ }^{3}$, K Gümüștaș ${ }^{2}$, A Belce ${ }^{2}$, V Etuš ${ }^{1}$ and E Özyurt ${ }^{1}$ \\ ${ }^{1}$ Department of Neurosurgery and ${ }^{2}$ Department of Biochemistry, Cerrahpașa Medical School, Istanbul University, \\ Istanbul; ${ }^{3}$ Department of Neurosurgery, Adnan Menderes University, Aydin, Turkey
}

\begin{abstract}
Study Design: The effect of epidural space perfusion with chilled saline solution (\% 0.9 $\mathrm{NaCl}$ ) on lipid peroxidation after experimental spinal cord injury in rats was evaluated.

Objectives: The extent of lipid peroxidation is a useful parameter for evaluating the cellular disturbance caused by spinal cord trauma in experimental conditions. The protective effects of hypothermia against neurological injury resulting from trauma or ischemia both in experimental and clinical situations have been demonstrated.

Setting: Departments of Neurosurgery and Biochemistry, Cerrahpaşa Medical School, Istanbul, Turkey.

Methods: Twenty-five female Wistar Albino rats were used. There were five rats in group I (sham-operated), seven rats in group II (trauma), and eight rats in group III (epidural cooling). The remaining five rats were used for the pilot study to determine the spinal cord and body temperature. A clip compression method was used to produce acute spinal cord injury. In group III, 30 min after the trauma the injured spinal cord was cooled by perfusion of the epidural space with chilled saline solution $(\% 0.9 \mathrm{NaCl})$ with a flow rate of $5 \mathrm{ml} / \mathrm{min}$ for $30 \mathrm{~min}$. At $2 \mathrm{~h}$ after trauma, all rats other than the ones used in the pilot study, were sacrificed and the spinal cords were excised. The extent of lipid peroxidation in the spinal cord was assessed by measuring the tissue content of malonil dialdehyde (MDA).

Results: The tissue MDA contents were 1.58 micromol MDA/gram wet weight (gww) in group 1 (sham-operated), $2.58 \mathrm{micromol} \mathrm{MDA} / \mathrm{gww}$ in group 2 (trauma), and $1.77 \mathrm{micromol} /$ gww in group 3 (epidural cooling), the differences being statistically significant.

Conclusion: The results indicated that epidural cooling of traumatized spinal cord is effective in preventing secondary damage due to the peroxidation of lipid membranes.
\end{abstract}

Keywords: epidural cooling; spinal cord injury; secondary damage

\section{Introduction}

The protective effects of hypothermia against neurological injury resulting from trauma or ischemia both in experimental $^{1-3}$ and clinical $^{4}$ situations have been demonstrated. $^{5-8}$ Experimental studies and clinical observations showed that spinal cord lesions are greatly enlarged by secondary injury. The molecular and cellular mechanisms underlying these events are still not clearly understood. Available evidence suggested that oxygen-radical formation and cell membrane lipid peroxidation have important roles in progressing secondary injury. ${ }^{9,10}$ Effectiveness of some therapeutic approaches has been evaluated by determining the level of lipid peroxidation in experimental conditions. ${ }^{11-14}$ To date, several different methods of hypothermia have been performed. Systemic hypothermia carries the risk of ventricular fibrillation and cardiac standstill. Negrin ${ }^{15}$ has shown that the central nervous system can tolerate $5^{\circ} \mathrm{C}$ without permanent

Correspondence: S Tüzgen, MD neurological complications. Regional cooling of the injured or ischemic spinal cord by different methods have been reported. ${ }^{1,16-19}$ In this study, we evaluated the effect of epidural space perfusion with chilled saline solution on lipid peroxidation after experimental spinal cord injury (SCI).

\section{Materials and methods}

Twenty five female Wistar Albino rats with weights ranging from $190-250 \mathrm{~g}$ were used. Rats were divided into three groups. There were five rats in group I, seven rats in group II and eight rats in group III. The remaining five rats were used for the pilot study. Rats were anesthetized with intraperitoneal injection of thiopentone sodium BP (pentothal sodium, Abbott) $30 \mathrm{mg} / \mathrm{kg}$, and two level laminectomy was performed at C7-T1 by using an operating microscope. The length of the exposed epidural space was 5-6 $\mathrm{mm}$. The clip (Technomedical TK 25132.00 aneurysm clip, force of 
closure $100-130 \mathrm{~g}$ ) was extradurally applied to the cord and remained compressing the cord for $40 \mathrm{~s}$ in group II and III. In group I, laminectomy was performed, but the clip was not applied. In group III, $30 \mathrm{~min}$ after the trauma, the injured spinal cord was cooled by perfusion of the epidural space with chilled $\left(10.5 \pm 9^{\circ} \mathrm{C}\right)$ saline solution $(\% 0.9 \mathrm{NaCl})$ with a constant flow rate of $5 \mathrm{ml} / \mathrm{min}$ for $30 \mathrm{~min}$. In the pilot study we measured the cord temperature before, and during epidural space perfusion cooling by inserting the tip of a thermocouple electrode $(0.5 \mathrm{~mm}$ in diameter) digital thermometer directly into the spinal cord, and the body temperature before and during cooling by a thermometer placed rectally in five rats. The cord temperature was $24-26^{\circ} \mathrm{C}$ when the systemic temperature was $31-34^{\circ} \mathrm{C}$. Two hours after the clip application, rats were sacrificed with large doses of pentothal sodium. The spinal cord was excised under the microscope and dura, and leptomeninges and blood vessels were separated from the spinal cord. This spinal cord, in length $1.5 \mathrm{~cm}$ with the traumatized part in middle, was stored at $-70^{\circ} \mathrm{C}$, until homogenization procedure.

In this study, lipid peroxidation was assessed by measuring the tissue content of MDA, one of the end products of lipid peroxidation. Tissue samples were homogenized in ice-cold trichloracetic acid (TCA) (1 tissue plus $1 \mathrm{ml} 10 \%$, wt/vol, TCA plus $8 \mathrm{ml} 5 \% \mathrm{wt} /$ vol, TCA, or equivalent amounts) in an Ultra Turrax tissue homogenizer. After centrifugation, a volume of the supernatant was added to an equal volume of 0.67 (wt/vol) thiobarbituric acid, and the mixture was heated $100^{\circ} \mathrm{C}$ for $10 \mathrm{~min}$. The absorption spectrum was then recorded over $480-600 \mathrm{~nm}$. The spectrum was quite similar to that obtained with an MDA standard produced by the acid hydrolysis of 1,1,3,3tetraethoxypropane and run under the same conditions. The MDA concentration was calculated from the absorption at $532 \mathrm{~nm}$ (absorption maximum) of the difference spectrum with the use of a molar extinction coefficient of $1.56 \times 100000$, as reported by others and also recalculated from our standards.

\section{Statistical analysis}

The results were analyzed by using SPSS $\mathrm{PC}+$ statistical solving pocket. One way ANOVA test was used. Differences between groups were determined by Mann-Whitney U Test. Differences were considered significant at a $P$ value of less than 0.05 .

\section{Results}

Spinal cord MDA contents were listed in Table 1. Difference of MDA level between group II (trauma group) and group I (sham-operated group) was statistically significant $(P<0.01)$. MDA levels in group III (epidural cooling group) were lower than group II, the difference was statistically significant $(P<0.01)$ indicating that epidural cooling of traumatized spinal
Table 1 Lipid peroxidation levels measured as malonil dialdehyde (MDA), and expressed as micromol MDA/gram wet weight (gww)

\begin{tabular}{|c|c|c|c|}
\hline & $\begin{array}{c}\text { Group I } \\
\text { Sham-operated } \\
\mathrm{n}=5\end{array}$ & $\begin{array}{c}\text { Group II } \\
\text { Trauma } \\
\mathrm{n}=7\end{array}$ & $\begin{array}{c}\text { Group III } \\
\text { Epidural } \\
\text { cooling } \\
\mathrm{n}=8\end{array}$ \\
\hline & $\begin{array}{l}1.365 \\
1.533 \\
1.901 \\
1.467 \\
1.643\end{array}$ & $\begin{array}{l}3.457 \\
2.369 \\
2.475 \\
1.887 \\
2.996 \\
2.653 \\
2.256\end{array}$ & $\begin{array}{l}1.564 \\
1.447 \\
2.374 \\
1.699 \\
1.917 \\
1.578 \\
1.831 \\
1.752\end{array}$ \\
\hline Mean \pm SD & $1.58 \pm 0.21$ & $2.58 \pm 0.51$ & $1.77+0.29$ \\
\hline
\end{tabular}

cord is effective in preventing peroxidation of lipid membranes.

\section{Discussion}

Our study showed that epidural cooling may have beneficial effects on spinal cord trauma in experimental conditions. The rationale for treatment of spinal cord injury is that the secondary damage could be preventable. Despite much research about the mechanisms of secondary tissue damage in spinal cord injury, our knowledge relating to these mechanisms remained incomplete.

Available evidence suggested that excessive release of the excitatory amino acid neurotransmitter glutamate and aspartate,$^{20-23}$ intracellular calcium overload, ${ }^{24-26}$ activation of the arachidonic acid cascade, ${ }^{27-29}$ and the induction of free radicals induced lipid peroxidation ${ }^{30}$ are the important pathways of the secondary injury process.

The relative importance of each of the pathways is unclear, but therapeutic approaches affecting each pathway have been developed and are being tested in laboratory and clinical situations. There is evidence for the importance of oxygen radical formation and cellmembrane lipid peroxidation in the injured nervous system. ${ }^{9,10,30,31}$ Lipid peroxidation is a progressing process that spreads over the surface of the cell membrane, inhibiting lipid dependent enzymes, disrupting ionic gradients, and, if severe enough, lysing membranes. ${ }^{32}$ Many researchers have shown that agents inhibiting lipid peroxidation enhance functional recovery in experimental CNS injuries. ${ }^{13,14,33,34}$ This concept was supported clinically by NASCIS II. ${ }^{35}$

The extent of lipid peroxidation is a useful parameter for evaluating the cellular disturbance caused by spinal cord trauma in experimental conditions. $^{13,14,33}$ There are several methods for measuring the degree of lipid peroxidation in tissue. These methods are measurement of thiobarbituric acid reactive substances (TBARS) content, determination 
of changes in diene conjugation aliquots of lipid extracts, and measurement of formation of lipid soluble fluorescent material. ${ }^{36}$ In this study, thiobarbituric acid test to measure MDA in homogenates was used because it was the test that we have been familiar with. ${ }^{37,38}$ Although the reaction of TBA with a complex variety of other molecules also provides a positive reaction, this can be acceptable if the results are compared with baseline lipid peroxidation levels obtained from the sham-operated group. The accuracy and appropriateness of the MDA test to measure the extent of lipid peroxidation in experimental conditions has been accepted by many investigators. ${ }^{36,39-42}$

It was shown that lipid peroxidation levels reached its maximum at $1 \mathrm{~h}$ after experimental spinal cord injury. ${ }^{39}$ Therefore, we have started the cooling procedure $30 \mathrm{~min}$ after the injury and continued for $30 \mathrm{~min}$. Perfusion of the injured or ischemic spinal cord with a cool, isotonic solution has been used in animal models ${ }^{1,3,6}$ and humans and has shown some promise $^{5-8}$

The potential beneficial effects of cooling seemed to be; decreased spinal cord metabolism, removal of accumulating toxins, and increased CSF circulation with greater delivery of nutrients to the damaged area. ${ }^{43}$ It was shown that hypothermia decreases the central nervous system oxygen metabolic rate and has a protective effect in ischemia. Leonov et $a l^{44}$ postulated a multifactorial mechanism describing how hypothermia may act: hypothermia quickly preserves high-energy phosphates, mitigates abnormal ion fluxes, reduces lactate production and tissue acidosis, free fatty acid production, and protects the fluidity of lipoprotein membranes.

To date, several different methods of hypothermia have been suggested for prevention of neurological injury resulting from trauma or ischemia. $1,16,45-48$ Systemic hypothermia carries some risk of cardiac disorders. Ventricular fibrillation and cardiac standstill may appear at a body temperature of below $32^{\circ} \mathrm{C}$, whereas central nervous system tissue may tolerate $5^{\circ} \mathrm{C}$ without permanent neurological complications. ${ }^{15}$

Techniques of selective cord hypothermia, either by perfusion or local application, have been shown to protect against neurological injury resulting from trauma both in experimental ${ }^{1,2}$ and clinical $^{4}$ situations. In the pilot study, we measured the cord temperature as $24-26^{\circ} \mathrm{C}$ when the systemic temperature was $31-34^{\circ} \mathrm{C}$ in five rats. We did not observe any cardiac arrhythmia with our technique.

Our results showed that cooling of the injured spinal cord is effective against secondary damage by lowering the lipid peroxidation. This protection may be attributed to several mechanisms. In an acidic environment, $\mathrm{O}_{2}$ is converted to the more reactive, more lipid-soluble hydroperoxil radical and its rate of dismutation to $\mathrm{H}_{2} \mathrm{O}_{2}$ is greatly increased. By reducing tissue acidosis and oxygen metabolic rate hypothermia may partly prevent production of free radicals and so may partly inhibit lipid peroxidation. There may be some other pathways of lipid peroxidation that hypothermia has affected. Effects of hypothermia on neurological outcome and histological findings have been previously investigated. The present study demonstrated the effectiveness of hypothermia biochemically in experimental spinal cord injury just for the early period of trauma.

\section{Acknowledgement}

We wish to express our thanks to Ayhan Metin for secretarial assistance.

\section{References}

1 Albin MS, White RJ, Acosta-Rua G, Yashon D. Study of functional recovery produced by delayed localized cooling after spinal cord injury in primates. J Neurosurg 1968; 29: 113-120.

2 Kuchner EF, Hansebout RR. Combined steroid and hypothermia treatment of experimental spinal cord injury. Surg Neurol 1976; 6: $371-380$.

3 Robertson CS, Foltz R, Grossman RG, Goodman JC. Protection against experimental ischemic spinal cord injury. $J$ Neurosurg 1986; 64: $633-642$.

4 Bricolo A, Dalle Ore G, Da Pian R, Faccioli F. Local cooling in spinal cord injury. Surg Neurol 1976; 6: 101-106.

5 Acosta Rua G. Treatment of traumatic paraplegic patients by localized cooling of the spinal cord. J Iowa Med Soc 1970; 60: $326-328$.

6 Hansebout RR. A comprehensive review of methods of improving cord recovery after acute spinal cord injury. In: $\mathrm{CH}$ Tator (ed.), Early Management of Acute Spinal Cord Injury, Raven Press: New York, 1982, pp 181-196.

7 Hansebout RR. The neurosurgical management of cord injuries. In: R Block and M Basbaum (eds), Management of Spinal Cord Injuries, Williams and Wilkins: Baltimore, 1986, pp 1-127.

8 Hansebout RR, Tanner JA, Romero-Sierra C. Current status of spinal cord cooling in the treatment of spinal cord injury. Spine 1984; 9: $508-511$.

9 Braughler JM, Hall ED. Central nervous system trauma and stroke, I. Biochemical considerations for oxygen radical formation and lipid peroxidation. Free Radic Biol Med 1989; 6: $2289-2301$.

10 Hall ED, Braughler JM. Central nervous system trauma and stroke, II. Physiological and pharmacological evidence for the involvement of oxygen radicals and lipid peroxidation. Free Radic Biol Med 1989; 6: 303-313.

11 Hall ED, Braughler JM. Acute effects of glucocorticoid pretreatment on the in vitro peroxidation of cat spinal tissue. Exp Neurol 1981; 73: 321 - 324 .

12 Hall ED, Braugler JM. Effect of intravenous methylprednisolone on spinal cord lipid peroxidation and $\left(\mathrm{Na}^{+}+\mathrm{K}^{+}\right)$-ATPase activity: dose-response analysis during 1 st hour after contusion injury in the cat. $J$ Neurosurg 1982; 57: 247-253.

13 Ildan $\mathrm{F}$ et al. Effects of naloxone on sodium and potassiumactivated and magnesium-dependent adenozine-5' -triphosphatase activity and lipid peroxidation and early ultrastructural findings after experimental spinal cord injury. Neurosurgery 1995; 36: $797-805$.

14 Koc RK et al. Lipid peroxidation in experimental spinal cord injury. Res Exp Med 1995; 195: 117-123.

15 Negrin J. The hypothermostat, an instrument to obtain local hypothermia of the brain or spinal cord. Int Surg 1970; 54: 93 106.

16 Coles JG, Wilson GJ, Sima AF. Intraoperative management of thoracic aortic aneurysm. Experimental evaluation of perfusion cooling of the spinal cord. J Thorac Cardiovasc Surg 1983; 85: $292-299$. 
17 Hansebout RR, Kuchner EF, Romero-Sierra C. Effects of local hypothermia and of steroids upon recovery from experimental spinal cord compression injury. Surgical Neurology 1975; 4: 531 536.

18 Salzano RP et al. Regional deep hypothermia of the spinal cord protects against ischemic injury during thoracic aortic crossclamping. Ann Thorac Surg 1994; 57: 65-71.

19 Tabayashi K, Niibori K, Kono H, Mohri H. Protection from post ischemic spinal cord injury by perfusion cooling of the epidural space. Ann Thorac Surg 1993; 56: 494- 498.

20 Faden AL, Lemke M, Simon RP, Noble LJ. N-methyl-Daspartate antagonist MK-801 improves outcome following traumatic spinal cord injury in rats: behavioral, anatomic and neurochemical studies. J Neurotrauma 1988; 5: 33 - 45.

21 Mac Dermott AB et al. NMDA-receptor activation increases cytoplasmic calcium concentration in culture spinal cord neurons. Nature 1986; 321: 519-522.

22 Olney JW, Ho OL, Rhee V. Cytotoxic effects of acidic and sulfurcontaining amino acids on the infant mouse central nervous system. Exper Brain Research 1971; 14: 61-67.

23 Pellegrini-Giampietro DE et al. Excitatory amino acid release and free radical formation may cooperate in the genesis of ischemia-induced neuronal damage. J Neurosci 1990; 10: 1035 1041.

24 Balentine JD, Hilton CW. Calcifications of axons in experimental spinal cord trauma. Annals of Neurology 1980; 2: 520-523.

25 Happel ED et al. $\mathrm{Ca}^{+}{ }^{+}$accumulation in experimental spinal cord trauma. Brain Res 1981; 211: 476-489.

26 Stokes BT, Fox P, Hollinden G. Extracellular calcium activity in the injured spinal cord. Exp Neurol 1983; 80: $561-572$.

27 Banik NL, Hogan EL, Hsu CY. Molecular and anatomical correlates of spinal cord injury. CNS Trauma 1985; 2: $99-107$.

28 Horrocks LA et al. The degradation of phospholipids, formation of metabolites of arachidonic acid, and demyelination following experimental spinal cord injury. CNS Trauma 1985; 2: $115-120$.

29 Jacobs TP et al. Thromboxane and S-Hete increase after experimental spinal cord injury in rabbits. CNS Trauma 1987 4: $95-118$.

30 Hall ED, Braughler JM. Role of lipid peroxidation in posttraumatic spinal cord degeneration: a review. CNS Trauma 1986; 3: $281-294$

31 Demopoulos HB, Flamm ES, Pietronigro DD, Seligman ML. The free radical pathology and the microcirculation in the major central nervous disorders. Acta Physiol Scand 1980; 492: 91 - 119

32 Hall ED, Traystman RJ. Secondary tissue damage after CNS injury. Current concepts, The Upjohn Company: Kalamazoo, Michigan, 1993, pp 12-13.

33 Hall ED. Neuroprotective actions of glucocorticoid and monoglucocorticoid steroids in acute neuronal injury. Cell $\mathrm{Mol}$ Neurobiol 1993; 13: 415-432
34 Hall ED, Braughler JM. Free radicals in CNS injury. Res Publ Assoc Res Nern Ment Dis 1993; 71: 81-105.

35 Bracken MB et al. A randomized, controlled trial of methylprednisolone or naloxone in the treatment of acute spinal cord injury, Results of the second NASCIS. N Engl J Med 1990; 322: $1405-1411$.

36 Halat $\mathrm{G}$ et al. Effect of partial ischemia on phospholipids and postischemic lipid peroxidation in rabbit spinal cord. Neurochem Res 1989; 14: 1089-1097.

37 Kaynar MY et al. Effect of nimodipine and n-acetylcysteine on lipid peroxidation after experimental spinal cord injury. Neurosurg Rev 1988; (in press)

38 Kaynar MY et al. The effect of duration of compression on lipid peroxidation after experimental spinal cord injury. Neurosurg Rev 1998; (in press).

39 Barut $\mathrm{S}$ et al. Lipid peroxidation in experimental spinal cord injury: time-level relationship. Neurosurg Rev 1993; 16: 53 - 59.

40 Lukacova N, Halat G, Chavko M, Marsala J. Ischemiareperfusion injury in the spinal cord of rabbits strongly enhances lipid peroxidation and modifies phospholipid profiles. Neurochem Res 1996; 21: 869-873

41 Nickander KK, McPhee BR, Low PA, Tritschler H. Alpha-lipoic acid: antioxidant potency against lipid peroxidation of neural tissues in vitro and implications for diabetic neuropathy. Free Radical Biol Med 1996; 21: 631 - 639

42 Stipek $\mathrm{S}$ et al. The effect of quinolinate on rat brain lipid peroxidation is dependent on iron. Neurochem Int 1997; 30: 233 237

43 Hirschfeld A, Young W. Trends in spinal cord injury research. In: Alderson JD and Frost EAM (eds), Spinal Cord Injuries. Anaesthetic and Associated Care, Butterworths: London 1990; pp $199-232$.

44 Leonov Y, Sterz F, Safar P. Mild cerebral hypothermia during and after cardiac arrest improves neurologic outcome in dog. $J$ Cereb Blood Flow Metab 1990; 10: 57-70.

45 Berguer R, Porto J, Fedoronko B. Selective deep hypothermia of the spinal cord prevents paraplegia after aortic cross-clamping in the dog model. J Vasc Surg 1992; 15: 62-71.

46 Negrin J, Klauber LD. Direct regional hypothermia of the central nervous system: a preliminary report of a pilot project on experimental hypothermia. Arch Neurol 1960; 3: 100.

47 Pontius RG et al. Use of hypothermia on the prevention of paraplegia following temporary aortic occlusion: experimental observations. Surgery 1954; 36: 33 - 38.

48 Vanicky I, Marsala M, Galik J, Marsala J. Epidural perfusion cooling protection against protracted spinal cord ischemia in rabbits. J Neurosurg 1993; 79: $736-741$. 